ISSN 0258-7122

Bangladesh J. Agril. Res. 37(2): 251-262, June 2012

\title{
INTEGRATED NUTRIENT MANAGEMENT FOR SUSTAINING SOIL FERTILITY THROUGH CHICKPEA-MUNGBEAN-T.AMAN CROPPING PATTERN AT MADARIPUR REGION
}

\author{
M. A. QUDDUS ${ }^{1}$, M. H. RASHID ${ }^{2}$, M. A. HOSSAIN ${ }^{3}$ \\ H. M. NASER ${ }^{4}$ AND J. ABEDIN MIAN ${ }^{5}$
}

\begin{abstract}
A field experiment was conducted on Chickpea-Mungbean-T.Aman cropping pattern at Pulses Research Sub-Station, Madaripur under Low Ganges River Floodplain Soils (AEZ-12) during 2007-08 and 2008-09 to find out the suitable fertilizer doses for this pattern. Four treatments were set up for each crop. For chickpea and mungbean, the treatments were $T_{1}=$ Recommended fertilizer dose as per FRG, 2005 BARC $\left(\mathrm{N}_{15} \mathrm{P}_{18} \mathrm{~K}_{10} \mathrm{~S}_{5} \mathrm{Zn}_{0.5} \mathrm{~B}_{0.5}\right)$; $\mathrm{T}_{2}=$ Soil test based fertilizer dose $\left(\mathrm{N}_{21} \mathrm{P}_{23} \mathrm{~K}_{30} \mathrm{~S}_{18} \mathrm{Zn}_{2} \mathrm{~B}_{1.5}\right)$; $\mathrm{T}_{3}=$ Farmers' practice $\left(\mathrm{N}_{23} \mathrm{P}_{15} \mathrm{~K}_{8}\right)$; and $\mathrm{T}_{4}=$ Control (without fertilizer). For T.Aman, the treatments were $\mathrm{T}_{1}=$ Recommended fertilizer dose as per FRG, BARC $\left(\mathrm{N}_{66} \mathrm{P}_{7} \mathrm{~K}_{12} \mathrm{~S}_{6} \mathrm{Zn}_{1}\right)$; $\mathrm{T}_{2}=$ Soil test based fertilizer dose $\left(\mathrm{N}_{130} \mathrm{P}_{14} \mathrm{~K}_{76} \mathrm{~S}_{6} \mathrm{Zn}_{1.5} \mathrm{~B}_{1.0}\right) ; \mathrm{T}_{3}=$ Farmer practice $\left(\mathrm{N}_{90} \mathrm{P}_{10} \mathrm{~K}_{15}\right)$; and $\mathrm{T}_{4}=$ control. Experimental results revealed that among the treatments the highest seed and stover/straw yields of chickpea (1524 kg/ha and $4049 \mathrm{~kg} / \mathrm{ha})$, mungbean (2208 kg/ha and $5121 \mathrm{~kg} / \mathrm{ha}$ ) and T.Aman (5414 kg/ha and $5615 \mathrm{~kg} / \mathrm{ha}$ ) were recorded in treatment $\mathrm{T}_{2}$. This treatment was significant at $5 \%$ level except seed yield of chickpea in 2008-09. $T_{3}$ treatment showed significant difference with $T_{4}$ treatment. The lowest seed and stover/straw yields of all the crops were recorded in control treatment $\left(\mathrm{T}_{4}\right)$. After completion of two years' pattern cycle, the organic matter, total nitrogen, phosphorus, sulphur, zinc, and boron were higher in treatment $T_{2}$. The economic analysis revealed that the highest BCR (2.57) was recorded in $T_{2}$, while the lowest value (2.14) was noted in $T_{4}$. Therefore, the soil test based fertilizer dose may be considered as suitable dose for this cropping pattern that ensure higher yield and increase soil fertility.
\end{abstract}

Keywords: Nutrient management, soil fertility, cropping pattern, productivity.

\section{Introduction}

In Bangladesh agriculture, rice dominates the crop sector occupying nearly $73 \%$ of the cropped area and contributing $70 \%$ of the value of output (Islam et al., 2007). Cultivation of HYVs of crops and adoption of modern technologies have led to severe depletion of nutrients from the soil. Generally, farmers use imbalanced chemical fertilizers for individual crop without considering cropping pattern for the whole year. As a result, a huge amount of fertilizers are being

\footnotetext{
${ }^{1,2}$ Senior Scientific Officer, Pulses Research Sub-station, Bangladesh Agricultural Research Institute (BARI), Madaripur, ${ }^{3}$ Senior Scientific Officer, PRSS, BARI, Gazipur, ${ }^{4}$ Senior Scientific Officer, Soil Science Division, BARI, Gazipur and ${ }^{5}$ Professor, Dept. of Soil Science, BAU, Mymensingh, Bangladesh.
} 
misused every year in crop cultivation (Noor et al., 2008). Intensive agriculture with very high nutrient turnover in soil-plant system coupled with low and imbalanced fertilizer use have resulted in deterioration of native soil fertility and created a serious threat to long-term sustainability of crop production (Anonymous, 2009).

The organic matter content and fertility status of Bangladesh soil is very low. It is well agreed that depleted soil fertility is the major constraint to higher crop production in Bangladesh and indeed, the yield of several crops are declining in some soils (Bhuian, 1991). So, integrated nutrient management is very important considering the residual effect of the nutrients. Moreover, inclusion of legume crops in the cropping pattern would reduce the requirement of chemical fertilizers in the next crop maintaining a good health of soils through biological nitrogen fixation (about 30-40 kg N/ha) and addition of organic matter to the soil (Sharma, 2005).

In Madaripur areas, a lion share of the cropped area is devoted to high yielding variety Boro rice cultivation to meet the increasing demand of rice for the growing population. The major cropping patterns followed in the study areas are Boro rice-Broadcast local aman and Lentil/chickpea-Jute-Fallow or Lentil/chickpea-Fallow-Aman rice. Many farmers in the study areas also cultivate lentil or chickpea as a single crop during Rabi season and keep their lands fallow for at least two months in between lentil/chickpea and Aman rice/jute crops. Mungbean is a short duration and leguminous crop (needs 50-70 days) and fallow periods can easily be utilized by introducing mungbean which can increase soil fertility in one hand and ensure farmers' monetary benefit on the other (Quddus et al., 2008). The farmers in the study areas have been practicing this cropping pattern (Chickpea-Mungbean-T.Aman) since 2006. But they have no recommended fertilizer dose for this pattern. Therefore, an attempt was made to find out suitable fertilizer doses for this pattern to sustain soil fertility, productivity, and crop yield.

\section{Materials and Method}

A field experiment was carried out on Chickpea-Mungbean-T.Aman cropping pattern at Pulses Research Sub-Station, Madaripur under Low Ganges River Floodplain Soils (AEZ-12) during 2007-2008 and 2008-2009 to evaluate the suitable fertilizers doses for sustaining soil fertility, productivity, and crop yields. There were four treatments along with control for each crop. For chickpea and mungbean, the treatments were $\mathrm{T}_{1}=$ Recommended fertilizer dose as per FRG, 2005 BARC $\left(\mathrm{N}_{15} \mathrm{P}_{18} \mathrm{~K}_{10} \mathrm{~S}_{5} \mathrm{Zn}_{0.5} \mathrm{~B}_{0.5}\right) ; \mathrm{T}_{2}=$ Soil test based fertilizer dose $\left(\mathrm{N}_{21} \mathrm{P}_{23} \mathrm{~K}_{30} \mathrm{~S}_{18} \mathrm{Zn}_{2} \mathrm{~B}_{1.5}\right)$; $\mathrm{T}_{3}=$ Farmers' practice $\left(\mathrm{N}_{23} \mathrm{P}_{15} \mathrm{~K}_{8}\right)$; and $\mathrm{T}_{4}=$ Control. The treatments for T.Aman were $\mathrm{T}_{1}=$ Recommended fertilizer dose as per FRG, 2005 
BARC $\left(\mathrm{N}_{66} \mathrm{P}_{7} \mathrm{~K}_{12} \mathrm{~S}_{6} \mathrm{Zn}_{1}\right) ; \quad \mathrm{T}_{2}=$ Soil test based fertilizer dose $\left(\mathrm{N}_{130} \mathrm{P}_{14} \mathrm{~K}_{76} \mathrm{~S}_{6} \mathrm{Zn}_{1.5} \mathrm{~B}_{1.0}\right)$; $\mathrm{T}_{3}=$ Farmers' practice $\left(\mathrm{N}_{90} \mathrm{P}_{10} \mathrm{~K}_{15}\right)$; and $\mathrm{T}_{4}=$ control.

Initial soil samples (0-15 cm depth) were collected from experimental field and dried in the air through passing a 2-mm sieve and analyzed their physical and chemical properties following standard methods. The sample soil was loamy in texture having $1 \%$ organic matter $(\mathrm{OM}), 0.075 \% \mathrm{~N}, 17 \mu \mathrm{g} / \mathrm{g} \mathrm{P}, 0.13$ meq.100/g K, $20 \mu \mathrm{g} / \mathrm{g} \mathrm{S,} 3.2$ meq.100/g Mg, $0.69 \mu \mathrm{g} / \mathrm{g} \mathrm{Zn}$ and $0.14 \mu \mathrm{g} / \mathrm{g}$ B. The soil $\mathrm{pH}$ was measured to be 7.0. Calculated amounts of all fertilizers of each treatments were applied to respective plot at the time of final land preparation except T.Aman, where urea was applied in 3 equal splits (first split was added after final land preparation, the second split after 3 weeks of transplanting, and the last split before panicle initiation stage).

The sources of N, P, K, S, Zn, and B were urea, triple super phosphate, muriate of potash, gypsum, zinc sulphate, and boric acid, respectively. The experiment was laid out in RCBD with three replications. The unit plot size was $4 \mathrm{~m} \times 3 \mathrm{~m}$ for each crop. Chickpea (BARI Chola-5) seeds were sown on 5 December 2007 and 8 December 2008 with a spacing of $50 \mathrm{~cm} \times 10 \mathrm{~cm}$. Mungbean seeds (BARI Mung-6) were sown on 28 March 2008 and on 1 April 2009 with a spacing of $40 \mathrm{~cm} \times 10 \mathrm{~cm}$. T. Aman (BRRI dhan 33) seedlings (30 days old) were transplanted on 23 July 2008 and on 22 July 2009 with a spacing of $20 \mathrm{~cm} \times 15 \mathrm{~cm}$. Intercultural operations were done when needed. The crops were harvested after maturity. Data on yield contributing characters of all crops were recorded from 10 randomly selected plants/hill from each plot. The seed and stover/straw yield $(\mathrm{kg} / \mathrm{ha})$ were recorded from whole plot. After completion of two cycles of the cropping pattern, soil samples were collected $(0-15 \mathrm{~cm}$ depth) from the same plots and chemical properties of soil were determined. Collected data were analyzed using MSTAT computer software.

\section{Results and Discussion}

\section{Yield contributing characters of chickpea}

The plant height of chickpea varied significantly due to different treatments (Table 1). Average of two years, the plant height ranged from 36.95 to $44.15 \mathrm{~cm}$. The highest plant height was recorded in $\mathrm{T}_{2}$ (soil test based fertilizer dose) treatment, which was statistically identical to $\mathrm{T}_{1}$ and $\mathrm{T}_{3}$ during 2008-09 and significantly higher over the other treatments during 2007-08. The maximum average number of pods per plant (46.15) was recorded in the treatment $T_{2}$ and the minimum value (36.55) was noted in the treatment $\mathrm{T}_{4}$. In 2007-08, the maximum number of pods per plant in $\mathrm{T}_{2}$ was significantly higher to all other treatments, but in 2008-09, the highest value noted in $T_{2}$ treatment was significantly at par with $\mathrm{T}_{1}$ only, but higher than rest of the treatments (Table 1). 
Table 1. Effect of nutrient management on plant height and number of pods/plant of chickpea under Chickpea-Mungbean-T.Aman cropping pattern.

\begin{tabular}{c|cccc|c|c|c}
\hline \multirow{2}{*}{ Treatment } & \multicolumn{3}{|c|}{ Plant height(cm) } & \multicolumn{3}{c}{ No. of pods/plant } \\
\cline { 2 - 7 } & $2007-08$ & $2008-09$ & Average & $2007-08$ & $2008-09$ & Average \\
\hline $\mathrm{T}_{1}$ & $43.67 \mathrm{~b}$ & $41.47 \mathrm{a}$ & 42.57 & $48.60 \mathrm{~b}$ & $36.80 \mathrm{a}$ & 42.70 \\
$\mathrm{~T}_{2}$ & $45.40 \mathrm{a}$ & $42.90 \mathrm{a}$ & 44.15 & $51.41 \mathrm{a}$ & $40.90 \mathrm{a}$ & 46.15 \\
$\mathrm{~T}_{3}$ & $43.40 \mathrm{~b}$ & $41.50 \mathrm{a}$ & 42.45 & $45.10 \mathrm{c}$ & $32.73 \mathrm{~b}$ & 38.91 \\
$\mathrm{~T}_{4}$ & $37.60 \mathrm{c}$ & $36.30 \mathrm{~b}$ & 36.95 & $40.60 \mathrm{~d}$ & $32.50 \mathrm{~b}$ & 36.55 \\
\hline $\mathrm{CV}(\%)$ & 1.09 & 1.92 & - & 1.23 & 2.10 & - \\
\hline
\end{tabular}

Values within the same column with a common letter do not differ significantly $(p=0.05)$

$\mathrm{T}_{1}=\mathrm{N}_{15} \mathrm{P}_{18} \mathrm{~K}_{10} \mathrm{~S}_{5} \mathrm{Zn}_{0.5} \mathrm{~B}_{0.5}, \mathrm{~T}_{2}=\mathrm{N}_{21} \mathrm{P}_{23} \mathrm{~K}_{30} \mathrm{~S}_{18} \mathrm{Zn}_{2} \mathrm{~B}_{1.5}, \mathrm{~T}_{3}=\mathrm{N}_{23} \mathrm{P}_{15} \mathrm{~K}_{8}$ and $\mathrm{T}_{4}=$ Control

Yield contributing characters like number of seeds per pod and 100 seed weight of chickpea showed significant difference due to nutrient management (Table 2). The maximum and minimum number of seeds per pod was recorded in the treatment $T_{2}$ and $T_{4}$, respectively, in both the years. The number of seeds per pod for $T_{1}$ and $T_{3}$ was statistically identical and higher than $T_{4}$ in both the years. One hundred seed weight was showed almost similar trend to the results of above characters. The average highest 100 -seed weight (11.88 g) was recorded in the treatment $T_{2}$ followed by $T_{1}$ treatment (11.53 g) and the lowest value (10.66 g) was recorded in the treatment $T_{4}$. The 100-seed weight as obtained from $T_{2}$ was statistically identical to $T_{1}$ but significantly higher than $T_{3}$ and $T_{4}$ during 2008-09 and significantly higher to all the treatments in 2007-08 (Table 2). Anonymous (2009) observed similar results where combination of nutrients showed significant response on yield contributing characters of chickpea. Yadav et al. (1997) reported that the phosphorus, $\mathrm{Zn}, \mathrm{Cu}, \mathrm{B}, \mathrm{Mo}$, and S promote the growth and development of the pulses and increase the productivity.

Table 2. Effect of nutrient management on number of seeds/pod and 100-seed weight of chickpea under Chickpea-Mungbean-T.Aman cropping pattern.

\begin{tabular}{c|cccccccc}
\hline \multirow{2}{*}{ Treatment } & \multicolumn{3}{|c|}{ No. of seeds/pod } & \multicolumn{3}{c}{ 100-seed wt (g) } \\
\cline { 2 - 7 } & $2007-08$ & $2008-09$ & Average & $2007-08$ & $2008-09$ & Average \\
\hline $\mathrm{T}_{1}$ & $1.42 \mathrm{ab}$ & $1.35 \mathrm{~b}$ & 1.38 & $11.93 \mathrm{~b}$ & $11.13 \mathrm{a}$ & 11.53 \\
$\mathrm{~T}_{2}$ & $1.47 \mathrm{a}$ & $1.42 \mathrm{a}$ & 1.44 & $12.53 \mathrm{a}$ & $11.23 \mathrm{a}$ & 11.88 \\
$\mathrm{~T}_{3}$ & $1.40 \mathrm{ab}$ & $1.33 \mathrm{~b}$ & 1.36 & $11.33 \mathrm{c}$ & $10.57 \mathrm{~b}$ & 10.95 \\
$\mathrm{~T}_{4}$ & $1.30 \mathrm{~b}$ & $1.25 \mathrm{c}$ & 1.27 & $10.93 \mathrm{c}$ & $10.40 \mathrm{~b}$ & 10.66 \\
\hline $\mathrm{CV}(\%)$ & 7.7 & 5.6 & - & 2.20 & 2.61 & - \\
\hline
\end{tabular}

Values within the same column with a common letter do not differ significantly $(p=0.05)$

$\mathrm{T}_{1}=\mathrm{N}_{15} \mathrm{P}_{18} \mathrm{~K}_{10} \mathrm{~S}_{5} \mathrm{Zn}_{0.5} \mathrm{~B}_{0.5}, \mathrm{~T}_{2}=\mathrm{N}_{21} \mathrm{P}_{23} \mathrm{~K}_{30} \mathrm{~S}_{18} \mathrm{Zn}_{2} \mathrm{~B}_{1.5}, \mathrm{~T}_{3}=\mathrm{N}_{23} \mathrm{P}_{15} \mathrm{~K}_{8}$ and $\mathrm{T}_{4}=$ Control 


\section{Yield of chickpea}

In both the years, the seed and stover yield of chickpea exhibited significant variation due to the nutrient management (Table 3). The highest average seed yield (1524 kg/ha) and stover yield (4049 kg/ha) were noted in the treatment $T_{2}$ and the lowest values $(957 \mathrm{~kg} / \mathrm{ha})$ and $(2752 \mathrm{~kg} / \mathrm{ha})$ were documented in the treatment $\mathrm{T}_{4}$ (Table 3 ). The highest seed yield of chickpea in $\mathrm{T}_{2}$ was significantly higher to all other treatments in 2007-08, but in 2008-09, it was significantly similar to $\mathrm{T}_{1}$ only and higher than rest of the treatments. Similarly, the maximum stover yield of chickpea in $T_{2}$ was significantly at par with $T_{1}$ treatment only in 2007-08, but it was significantly higher than all the treatments in 2008-09. Harun et al. (2009) observed that the combination of $\mathrm{Zn}_{2.5} \mathrm{~B}_{1.0}$ with blanket dose of macro nutrient gave the highest seed yield (1.70t/ha) of chickpea. Sakal et al. (1988) reported on a coarse textured highly calcareous soil that application of 2.0 and $2.5 \mathrm{~kg} \mathrm{~B} / \mathrm{ha}$ with blanket dose of other nutrient increased seed yield of chickpea by $38 \%$. These results were in agreement with those reported by Bharti et al. (2002) and Islam (2005).

Table 3. Effect of nutrient management on seed and stover yield of chickpea under Chickpea-Mungbean-T.Aman cropping pattern.

\begin{tabular}{c|cccc|c|c|}
\hline \multirow{2}{*}{ Treatment } & \multicolumn{3}{|c|}{ Seed yield (kg/ha) } & \multicolumn{3}{c}{ Stover yield (kg/ha) } \\
\cline { 2 - 7 } & $2007-08$ & $2008-09$ & Average & $2007-08$ & $2008-09$ & Average \\
\hline $\mathrm{T}_{1}$ & $1410 \mathrm{~b}$ & $1122 \mathrm{ab}$ & 1266 & $3941 \mathrm{ab}$ & $3340 \mathrm{~b}$ & 3641 \\
$\mathrm{~T}_{2}$ & $1685 \mathrm{a}$ & $1363 \mathrm{a}$ & 1524 & $4197 \mathrm{a}$ & $3900 \mathrm{a}$ & 4049 \\
$\mathrm{~T}_{3}$ & $1287 \mathrm{~b}$ & $953 \mathrm{~b}$ & 1120 & $3667 \mathrm{~b}$ & $3006 \mathrm{~b}$ & 3337 \\
$\mathrm{~T}_{4}$ & $1080 \mathrm{c}$ & $833 \mathrm{c}$ & 957 & $3061 \mathrm{c}$ & $2442 \mathrm{c}$ & 2752 \\
\hline $\mathrm{CV}(\%)$ & 4.04 & 2.79 & - & 5.45 & 6.87 & - \\
\hline
\end{tabular}

Values within the same column with a common letter do not differ significantly $(p=0.05)$

$\mathrm{T}_{1}=\mathrm{N}_{15} \mathrm{P}_{18} \mathrm{~K}_{10} \mathrm{~S}_{5} \mathrm{Zn}_{0.5} \mathrm{~B}_{0.5}, \mathrm{~T}_{2}=\mathrm{N}_{21} \mathrm{P}_{23} \mathrm{~K}_{30} \mathrm{~S}_{18} \mathrm{Zn}_{2} \mathrm{~B}_{1.5}, \mathrm{~T}_{3}=\mathrm{N}_{23} \mathrm{P}_{15} \mathrm{~K}_{8}$ and $\mathrm{T}_{4}=$ Control

\section{Yield contributing characters of mungbean}

The plant height of mungbean significantly varied under different treatments (Table 4). Average of two years, the highest plant height $(45.38 \mathrm{~cm})$ of mungbean was recorded in the treatment $T_{2}$, which was statistically identical to $\mathrm{T}_{1}$. The lowest value $(39.50 \mathrm{~cm})$ was being noted in the treatment $\mathrm{T}_{4}$. The impact of nutrient management on number of pods per plant was also significant (Table 4). The response trend was similar as before. The highest mean number of pods per plant (23.10) was recorded in $\mathrm{T}_{2}$, which was statistically significant and higher than which other treatments (Table 4). Ved Ram et al. (2008) found positive effects of N, P, K, S and Zn application on the plant height and pods per 
plant. Verma and Mishra (1999) reported that when boron was applied in soil or foliar spraying, it increased the mungbean yield and growth parameters.

Table 4. Effect of nutrient management on plant height and number of pods/plant of mungbean under Chickpea-Mungbean-T.Aman cropping pattern.

\begin{tabular}{c|c|c|c|c|c|c}
\hline \multirow{2}{*}{ Treatment } & \multicolumn{3}{|c|}{ Plant height $(\mathrm{cm})$} & \multicolumn{3}{c}{ No. of pods/plant } \\
\cline { 2 - 7 } & $2007-08$ & $2008-09$ & Average & $2007-08$ & $2008-09$ & Average \\
\hline $\mathrm{T}_{1}$ & $42.97 \mathrm{~b}$ & $45.07 \mathrm{a}$ & 44.02 & $22.07 \mathrm{~b}$ & $21.20 \mathrm{~b}$ & 21.64 \\
$\mathrm{~T}_{2}$ & $45.37 \mathrm{a}$ & $45.40 \mathrm{a}$ & 45.38 & $23.90 \mathrm{a}$ & $22.30 \mathrm{a}$ & 23.10 \\
$\mathrm{~T}_{3}$ & $42.60 \mathrm{~b}$ & $42.30 \mathrm{~b}$ & 42.45 & $21.00 \mathrm{c}$ & $20.57 \mathrm{c}$ & 20.79 \\
$\mathrm{~T}_{4}$ & $39.00 \mathrm{c}$ & $40.00 \mathrm{c}$ & 39.50 & $16.10 \mathrm{~d}$ & $15.87 \mathrm{~d}$ & 15.98 \\
\hline $\mathrm{CV}(\%)$ & 1.19 & 0.58 & - & 1.60 & 0.20 & - \\
\hline
\end{tabular}

Values within the same column with a common letter do not differ significantly $(p=0.05)$

$\mathrm{T}_{1}=\mathrm{N}_{15} \mathrm{P}_{18} \mathrm{~K}_{10} \mathrm{~S}_{5} \mathrm{Zn}_{0.5} \mathrm{~B}_{0.5}, \mathrm{~T}_{2}=\mathrm{N}_{21} \mathrm{P}_{23} \mathrm{~K}_{30} \mathrm{~S}_{18} \mathrm{Zn}_{2} \mathrm{~B}_{1.5}, \mathrm{~T}_{3}=\mathrm{N}_{23} \mathrm{P}_{15} \mathrm{~K}_{8}$ and $\mathrm{T}_{4}=$ Control

Number of seeds per pod and 100-seed weight of mungbean were significantly benefited by different nutrient managements (Table 5). The average maximum and minimum number of seeds per pod (8.68) and (7.44) were recorded in the treatment $T_{2}$ and $T_{4}$, respectively. In the first season (2007-08), the highest number of seeds per pod (9.01) was recorded in $T_{2}$, which was statistically higher than all other treatments, but statistically identical with $\mathrm{T}_{1}$ during 2008-09. The average highest 100 -seed weight (5.76 g) was recorded in the treatment $T_{2}$ followed by (5.67 $\mathrm{g}$ ) in $T_{1}$ treatment and the lowest (5.43 g) was recorded in the treatment $\mathrm{T}_{4}$ (Table 5). Ved Ram et al. (2008) also observed that the application of $\mathrm{N}, \mathrm{P}, \mathrm{K}, \mathrm{S}$, and $\mathrm{Zn}$ nutrients favoured the seeds per pod and 1000-seed weight. Abdo (2001) expressed the similar view that foliar spray with the adopted concentration of $\mathrm{Zn}, \mathrm{Mn}$ or $\mathrm{B}$ alone or in mixture of all nutrients increased significantly most of the growth parameters of mungbean over the control. Anonymous (2000) observed that B application increased the number of pods/ per plant and seeds/pod.

Table 5. Effect of nutrient management on number of seeds/pod and 100 seed weight of mungbean under Chickpea-Mungbean-T.Aman cropping pattern.

\begin{tabular}{c|cccc|ccc}
\hline \multirow{2}{*}{ Treatment } & \multicolumn{3}{|c|}{ No. of seeds/pod } & \multicolumn{3}{c}{ 100-seed wt (g) } \\
\cline { 2 - 7 } & $2007-08$ & $2008-09$ & Average & $2007-08$ & $2008-09$ & Average \\
\hline $\mathrm{T}_{1}$ & $8.39 \mathrm{~b}$ & $8.15 \mathrm{a}$ & 8.27 & $5.83 \mathrm{a}$ & $5.50 \mathrm{~b}$ & 5.67 \\
$\mathrm{~T}_{2}$ & $9.01 \mathrm{a}$ & $8.35 \mathrm{a}$ & 8.68 & $5.93 \mathrm{a}$ & $5.60 \mathrm{a}$ & 5.76 \\
$\mathrm{~T}_{3}$ & $7.90 \mathrm{c}$ & $7.85 \mathrm{~b}$ & 7.87 & $5.70 \mathrm{~b}$ & $5.47 \mathrm{~b}$ & 5.59 \\
$\mathrm{~T}_{4}$ & $7.55 \mathrm{c}$ & $7.34 \mathrm{~b}$ & 7.44 & $5.47 \mathrm{c}$ & $5.40 \mathrm{c}$ & 5.43 \\
\hline CV (\%) & 3.15 & 3.55 & - & 0.96 & 0.53 & - \\
\hline
\end{tabular}

Values within the same column with a common letter do not differ significantly ( $\mathrm{p}=0.05$ )

$\mathrm{T}_{1}=\mathrm{N}_{15} \mathrm{P}_{18} \mathrm{~K}_{10} \mathrm{~S}_{5} \mathrm{Zn}_{0.5} \mathrm{~B}_{0.5}, \mathrm{~T}_{2}=\mathrm{N}_{21} \mathrm{P}_{23} \mathrm{~K}_{30} \mathrm{~S}_{18} \mathrm{Zn}_{2} \mathrm{~B}_{1.5}, \mathrm{~T}_{3}=\mathrm{N}_{23} \mathrm{P}_{15} \mathrm{~K}_{8}$ and $\mathrm{T}_{4}=$ Control 


\section{Yield of mungbean}

Nutrient managements have created significant impact on seed and stover yield of mungbean (Table 6). The highest average seed yield (2208 kg/ha) and stover yield (5121 kg/ha) were found in the treatment $T_{2}$ and the lowest values (1556 $\mathrm{kg} / \mathrm{ha}$ ) and (4576 kg/ha) were in the treatment $\mathrm{T}_{4}$. The highest seed and stover yield in both the years were recorded in $\mathrm{T}_{2}$ (soil test based fertilizer dose), which were significantly higher than all other treatments. Kumar and Singh (2009) reported that balanced application of N, P, K, S, and Zn significantly increased the yield (2154 kg/ha) of mungbean. Biswas et al. (2009) found similar results where fertilizer management practice $\left(\mathrm{N}_{20} \mathrm{P}_{20} \mathrm{~K}_{20} \mathrm{~S}_{10} \mathrm{Zn}_{2}\right)$ favoured seed yield (1214 kg/ha). The same phenomena were also observed by Verma and Mishra (1999).

Table 6. Effect of nutrient management on seed and stover yield of mungbean under Chickpea-Mungbean-T.Aman cropping pattern.

\begin{tabular}{c|cccc|c|c|c}
\hline \multirow{2}{*}{ Treatment } & \multicolumn{3}{|c|}{ Seed yield (kg/ha) } & \multicolumn{3}{c}{ Stover yield (kg/ha) } \\
\cline { 2 - 7 } & $2007-08$ & $2008-09$ & Average & $2007-08$ & $2008-09$ & Average \\
\hline $\mathrm{T}_{1}$ & $2062 \mathrm{~b}$ & $1828 \mathrm{~b}$ & 1945 & $5043 \mathrm{~b}$ & $4833 \mathrm{~b}$ & 4938 \\
$\mathrm{~T}_{2}$ & $2295 \mathrm{a}$ & $2121 \mathrm{a}$ & 2208 & $5292 \mathrm{a}$ & $4950 \mathrm{a}$ & 5121 \\
$\mathrm{~T}_{3}$ & $1850 \mathrm{c}$ & $1658 \mathrm{c}$ & 1754 & $4938 \mathrm{~b}$ & $4795 \mathrm{~b}$ & 4867 \\
$\mathrm{~T}_{4}$ & $1598 \mathrm{~d}$ & $1514 \mathrm{~d}$ & 1556 & $4642 \mathrm{c}$ & $4510 \mathrm{c}$ & 4576 \\
\hline $\mathrm{CV}(\%)$ & 1.80 & 1.19 & - & 2.00 & 1.56 & - \\
\hline
\end{tabular}

Values within the same column with a common letter do not differ significantly $(\mathrm{p}=0.05)$

$\mathrm{T}_{1}=\mathrm{N}_{15} \mathrm{P}_{18} \mathrm{~K}_{10} \mathrm{~S}_{5} \mathrm{Zn}_{0.5} \mathrm{~B}_{0.5}, \mathrm{~T}_{2}=\mathrm{N}_{21} \mathrm{P}_{23} \mathrm{~K}_{30} \mathrm{~S}_{18} \mathrm{Zn}_{2} \mathrm{~B}_{1.5}, \mathrm{~T}_{3}=\mathrm{N}_{23} \mathrm{P}_{15} \mathrm{~K}_{8}$ and $\mathrm{T}_{4}=$ Control

Table 7. Effect of nutrient management on plant height and number of tillers/hill of T.Aman under Chickpea-Mungbean-T.Aman cropping pattern.

\begin{tabular}{c|c|c|c|c|c|c}
\hline \multirow{2}{*}{ Treatment } & \multicolumn{3}{|c|}{ Plant height (cm) } & \multicolumn{3}{c}{ No. of tillers/hill } \\
\cline { 2 - 7 } & $2007-08$ & $2008-09$ & Average & $2007-08$ & $2008-09$ & Average \\
\hline $\mathrm{T}_{1}$ & $99.37 \mathrm{~b}$ & $97.83 \mathrm{~b}$ & 98.60 & $12.67 \mathrm{~b}$ & $12.30 \mathrm{~b}$ & 12.48 \\
$\mathrm{~T}_{2}$ & $107.6 \mathrm{a}$ & $104.3 \mathrm{a}$ & 105.95 & $15.13 \mathrm{a}$ & $14.93 \mathrm{a}$ & 15.03 \\
$\mathrm{~T}_{3}$ & $96.20 \mathrm{c}$ & $93.70 \mathrm{c}$ & 94.95 & $11.27 \mathrm{c}$ & $11.10 \mathrm{c}$ & 11.18 \\
$\mathrm{~T}_{4}$ & $82.83 \mathrm{~d}$ & $81.70 \mathrm{~d}$ & 82.26 & $8.80 \mathrm{~d}$ & $8.99 \mathrm{~d}$ & 8.89 \\
\hline $\mathrm{CV}(\%)$ & 1.14 & 0.15 & - & 6.15 & 5.85 & - \\
\hline
\end{tabular}

Values within the same column with a common letter do not differ significantly $(p=0.05)$

$\mathrm{T}_{1}=\mathrm{N}_{66} \mathrm{P}_{7} \mathrm{~K}_{12} \mathrm{~S}_{6} \mathrm{Zn}_{1}, \mathrm{~T}_{2}=\mathrm{N}_{130} \mathrm{P}_{14} \mathrm{~K}_{76} \mathrm{~S}_{6} \mathrm{Zn}_{1.5} \mathrm{~B}_{1.0}, \mathrm{~T}_{3}=\mathrm{N}_{90} \mathrm{P}_{10} \mathrm{~K}_{15}$ and $\mathrm{T}_{4}=$ control 


\section{Yield contributing characters of T.Aman}

Balanced applications of plant nutrients have significantly favoured the plant height and number of tillers per hill of T.Aman rice crop (Table 7). The highest average plant height $(105.95 \mathrm{~cm})$ and number of tillers per hill $(15.03)$ were recorded in the treatment $T_{2}$ and the lowest $(82.26 \mathrm{~cm}$ and 8.89$)$ were recorded from the treatment $T_{4}$. The highest plant height and tillers per hill were recorded in $T_{2}$, which were significantly higher than other treatments in both the years.

The response of number of seeds per panicle to different treatments was the same as before and the highest average number of seed per panicle (163) was observed in $T_{2}$, the lowest value (116) being noted in $T_{4}$ treatment. The highest number of seeds in $T_{2}$ was significantly higher than those recorded in rest of the treatments in 2007-08 season, but it was significantly at par with $\mathrm{T}_{1}$ only in 200809 (Table 8). As before, the highest average 1000-seed weight (26.08 g) was recorded in the treatment $T_{2}$ and the lowest (24.58 g) was recorded in the treatment $T_{4}$ (Table 8). The second highest 1000-seed weight was found in the treatment $T_{1}$ was statistically identical to $T_{3}$ during 2007-08 and to $T_{3}, T_{4}$ during 2008-09 (Table 8). The same result was observed (Rahman et al., 2009).

Table 8. Effect of nutrient management on number of seeds/panicle and 1000-seed weight of T.Aman under Chickpea-Mungbean-T.Aman cropping pattern.

\begin{tabular}{c|cccc|c|c|c}
\hline \multirow{2}{*}{ Treatment } & \multicolumn{3}{|c|}{ No. of seeds/panicle } & \multicolumn{3}{c}{1000 -seed wt (g) } \\
\cline { 2 - 7 } & $2007-08$ & $2008-09$ & Average & $2007-08$ & $2008-09$ & Average \\
\hline $\mathrm{T}_{1}$ & $150 \mathrm{~b}$ & $152 \mathrm{a}$ & 151 & $24.90 \mathrm{~b}$ & $25.50 \mathrm{~b}$ & 25.20 \\
$\mathrm{~T}_{2}$ & $164 \mathrm{a}$ & $162 \mathrm{a}$ & 163 & $25.97 \mathrm{a}$ & $26.20 \mathrm{a}$ & 26.08 \\
$\mathrm{~T}_{3}$ & $139 \mathrm{c}$ & $140 \mathrm{~b}$ & 140 & $24.67 \mathrm{bc}$ & $25.20 \mathrm{~b}$ & 24.94 \\
$\mathrm{~T}_{4}$ & $116 \mathrm{~d}$ & $115 \mathrm{c}$ & 116 & $24.27 \mathrm{c}$ & $24.90 \mathrm{~b}$ & 24.58 \\
\hline $\mathrm{CV}(\%)$ & 2.10 & 3.12 & - & 1.06 & 1.27 & - \\
\hline
\end{tabular}

Values within the same column with a common letter do not differ significantly $(p=0.05)$

$\mathrm{T}_{1}=\mathrm{N}_{66} \mathrm{P}_{7} \mathrm{~K}_{12} \mathrm{~S}_{6} \mathrm{Zn}_{1}, \mathrm{~T}_{2}=\mathrm{N}_{130} \mathrm{P}_{14} \mathrm{~K}_{76} \mathrm{~S}_{6} \mathrm{Zn}_{1.5} \mathrm{~B}_{1.0}, \mathrm{~T}_{3}=\mathrm{N}_{90} \mathrm{P}_{10} \mathrm{~K}_{15}$ and $\mathrm{T}_{4}=$ control

\section{Yield of T.Aman}

The seed and straw yield of T.Aman responded significantly to nutrient management (Table 9). The highest mean seed yield (5414 kg/ha) and straw yield (5615 kg/ha) were found in the treatment $T_{2}$ and the lowest amount (3371 kg/ha) and $(3509 \mathrm{~kg} / \mathrm{ha})$ was noted in the treatment $\mathrm{T}_{4}$. The highest seed and straw yield found in $T_{2}$ was statistically higher over the other treatments in both the years (Table 9). Rahman et al. (2009) observed that the seed and straw yield of T.Aman was favoured by balanced nutrient application. The same result was observed by (Biswas et al., 2009). Gupta and Mehla (1993) reported that 
application of 180,90 , and $90 \mathrm{~kg} / \mathrm{ha}$ of $\mathrm{N}, \mathrm{P}_{2} \mathrm{O}_{5}$, and $\mathrm{K}_{2} \mathrm{O}$ (high fertility), respectively, enhanced the yield of both rice and wheat crops. Islam et al. (1996) referred the same agreement that the highest seed yield of rice was obtained with $\mathrm{S}+\mathrm{Zn}+\mathrm{B}$ application which showed $42 \%$ yield increase over control.

Table 9. Effect of nutrient management on seed and straw yield of T.Aman under Chickpea-Mungbean-T.Aman cropping pattern.

\begin{tabular}{c|ccccccc}
\hline \multirow{2}{*}{ Treatment } & \multicolumn{3}{|c|}{ Seed yield (kg/ha) } & \multicolumn{3}{c}{ Straw yield (kg/ha) } \\
\cline { 2 - 7 } & $2007-08$ & $2008-09$ & Average & $2007-08$ & $2008-09$ & Average \\
\hline $\mathrm{T}_{1}$ & $5009 \mathrm{~b}$ & $5000 \mathrm{~b}$ & 5005 & $5173 \mathrm{~b}$ & $5108 \mathrm{~b}$ & 5141 \\
$\mathrm{~T}_{2}$ & $5432 \mathrm{a}$ & $5395 \mathrm{a}$ & 5414 & $5673 \mathrm{a}$ & $5557 \mathrm{a}$ & 5615 \\
$\mathrm{~T}_{3}$ & $4517 \mathrm{c}$ & $4488 \mathrm{c}$ & 4503 & $4827 \mathrm{c}$ & $4804 \mathrm{~b}$ & 4816 \\
$\mathrm{~T}_{4}$ & $3307 \mathrm{~d}$ & $3435 \mathrm{~d}$ & 3371 & $3423 \mathrm{~d}$ & $3594 \mathrm{c}$ & 3509 \\
\hline $\mathrm{CV}(\%)$ & 1.84 & 1.71 & - & 1.95 & 2.10 & - \\
\hline
\end{tabular}

Values within the same column with a common letter do not differ significantly $(\mathrm{p}=0.05)$ $\mathrm{T}_{1}=\mathrm{N}_{66} \mathrm{P}_{7} \mathrm{~K}_{12} \mathrm{~S}_{6} \mathrm{Zn}_{1}, \mathrm{~T}_{2}=\mathrm{N}_{130} \mathrm{P}_{14} \mathrm{~K}_{76} \mathrm{~S}_{6} \mathrm{Zn}_{1.5} \mathrm{~B}_{1.0}, \mathrm{~T}_{3}=\mathrm{N}_{90} \mathrm{P}_{10} \mathrm{~K}_{15}$ and $\mathrm{T}_{4}=$ Control

Table 10. Fertility status of initial and post harvest soil.

\begin{tabular}{|c|c|c|c|c|c|c|c|c|c|c|c|}
\hline & \multirow{2}{*}{$\mathrm{pH}$} & \multirow{2}{*}{$\begin{array}{l}\text { OM } \\
\text { (\%) }\end{array}$} & \multirow{2}{*}{$\begin{array}{c}\text { Total } \\
\text { N } \\
(\%)\end{array}$} & $\mathrm{Ca}$ & $\mathrm{Mg}$ & K & $\mathrm{P}$ & $\mathrm{S}$ & Mn & Zn & B \\
\hline & & & & \multicolumn{3}{|c|}{ Meq/100 g } & \multicolumn{5}{|c|}{$\mu \mathrm{g} / \mathrm{g}$} \\
\hline Treatment Initial & 7.0 & 1.00 & 0.075 & 11.0 & 3.2 & 0.13 & 17 & 20 & 10 & 0.69 & 0.14 \\
\hline $\mathrm{T}_{1}$ & 7.2 & 1.32 & 0.090 & 11.5 & 3.3 & 0.23 & 24 & 21 & 12 & 1.01 & 0.18 \\
\hline $\mathrm{T}_{2}$ & 7.3 & 1.48 & 0.095 & 12.1 & 3.3 & 0.25 & 27 & 25 & 14 & 1.10 & 0.18 \\
\hline $\mathrm{T}_{3}$ & 7.2 & 1.28 & 0.080 & 11.3 & 3.1 & 0.22 & 25 & 19 & 11 & 0.67 & 0.13 \\
\hline $\mathrm{T}_{4}$ & 7.2 & 1.25 & 0.076 & 11.1 & 3.0 & 0.11 & 15 & 13 & 11 & 0.67 & 0.12 \\
\hline
\end{tabular}

\section{Soil fertility status}

Initially the soil $\mathrm{pH}$ was 7.0, but after completion of two years' pattern cycle as well as incorporation of mungbean stover in soil, the soil $\mathrm{pH}$ slightly increased in all the treatments. The nutrient status of soil showed variation in macro and micro nutrients. The highest amount of organic matter and total N, P, S, Zn, and $B$ were found in $T_{2}$ treatment where high amount of mungbean biomass was added. The organic matter status was considerably improved due to the incorporation of mungbean stover to soil. Such observations are in agreement with the findings of Badanur et al. (1990), Bhardwaj and Omanwar (1994) and Zaman et al. (1994). It was also found that the fertility status of soil that is the 
OM, total N, P, K, S, Mn, Zn, and B content in soil were increased over the initial soil (Table 10). Ahlawat and Srivastava (1997) observed that incorporation of mungbean stover after picking of pods resulted in reduction of application of about $23 \mathrm{~kg}$ N/ha to the succeeding crop. Rao and Bhardwaj (1980) conclusively proved that pulses receiving optimum fertilizer, especially $\mathrm{P}$ had more pronounced residual effect both in terms of $\mathrm{N}$ and $\mathrm{P}$ in succeeding cereals.

Table 11. Cost and return analysis of Chickpea-Mungbean-T.Aman cropping pattern affected by nutrient management (Average of two years completed pattern cycle).

\begin{tabular}{c|c|c|c|c}
\hline Treatment & $\begin{array}{c}\text { Variable cost } \\
\text { Tk./ha/yr. }\end{array}$ & $\begin{array}{c}\text { Gross return } \\
\text { Tk./ha/yr. }\end{array}$ & $\begin{array}{c}\text { Gross margin } \\
\text { Tk./ha/yr. }\end{array}$ & BCR \\
\hline $\mathrm{T}_{1}$ & 94626 & 241208 & 146582 & 2.54 \\
$\mathrm{~T}_{2}$ & 106712 & 274277 & 167565 & 2.57 \\
$\mathrm{~T}_{3}$ & 92459 & 216411 & 123952 & 2.34 \\
$\mathrm{~T}_{4}$ & 83769 & 179515 & 95746 & 2.14 \\
\hline
\end{tabular}

$\mathrm{T}_{1}=$ Recommended fertilizer dose, $\mathrm{T}_{2}=$ Soil test based fertilizer dose, $\mathrm{T}_{3}=$ Farmers' practice, and $\mathrm{T}_{4}=$ Control

Input prices (Tk./kg) : Urea= 12, T.S.P= 22, M.P= 25, Gypsum= 6, Zinc sulphate $=120$, Boric acid $=120$, Chickpea seed $=70$, Mungbean seed $=60$, Aman rice seed $=40$, Irrigation $=$ Tk. 50 per hour, Wage rate $=$ Tk. 120 per day and Ploughing $=$ Tk. 120 per bigha per ploughing.

Output price (Tk./kg): Chickpea= 56, Mungbea $=45$, $\mathrm{T}$ Aman rice $=15$ and Rice straw= 1.5 .

\section{Cost and Return}

Regarding cost and return analysis, it was found that the highest gross margin (167565 Tk./ha/yr) was obtained from the treatment $\mathrm{T}_{2}$ and the lowest (95746 Tk./ha/yr) was obtained from the treatment $\mathrm{T}_{4}$. However, the highest BCR (2.57) was found in $\mathrm{T}_{2}$ and the lowest BCR (2.14) was recorded in $\mathrm{T}_{4}$ (Table 11).

\section{Conclusion}

Results of two years' trials clearly indicated that the yields of seed and stover/straw for chickpea, mungbean, and T.Aman are found to be the highest in treatment $T_{2}$. Besides this, the organic matter, total nitrogen, phosphorus, sulphur, zinc, and boron are also higher in treatment $T_{2}$, which is economically profitable also. Therefore, the soil test based fertilizer dose may be considered as suitable dose for the cropping pattern Chickpea-Mungbean-T.Aman and sustain soil fertility in Low Ganges River Floodplain Soils of Madaripur. 


\section{References}

Abdo, F.A. 2001. The response of two mungbean cultivers to zinc, manganese and boron I. Morphological, physiological and anatomical aspects. Bull. Fac. Agric., Cairo Univ. 52(3): 445-466.

Ahlawat, I.P.S. and T.K. Srivastava. 1997. Fertility management in pulse based cropping systems. Pages 509-523. In: Recent Advances in Pulses Research (Eds. Asthana AN and Masood Ali). Indian Soceity of Pulses Research and Development, IIPR, Kanpur, India.

Anonymous. 2009. 25 Years of Pulses Research at IIPR, 1984-2009 (Eds. Shiv Kumar and Mohan Singh), Published by: Indian Institute of Pulses Research, Kanpur 208024, India.

Anonymous.2000. Annual Report, Soil Management Collaborative Research Support Project, 1999-2000.

Badanur, V.P., C.N. Poleshi, and B.K. Nack. 1990. Effects of organic matter on crop yield, physical and chemical properties of vertisols. J. Indian Soc. Soil Sci. 38: 426428.

Bhardwaj, V. and P.K. Omanwar.1994. Long term effects of continuous rotational cropping and fertilizer on crop yield and soil properties: 11. Effects on EC, $\mathrm{pH}$, organic matter and available nutrients of rice. J. Indian Soc. Soil Sci. 42: 387-392.

Bharti, N., M. Murtaza and A.P. Singh. 2002. Effect of boron Rhizobium relationship on yield, nitrogen and boron nutrition of chickpea. J. Res. Birsa Agric. Univ. 14(2): 175179.

Bhuiyan, N.I. 1991. Issues concerning declining/stagnating productivity in Bangladesh Agriculture. A paper presented at the National Workshop on Risk Management in Bangladesh Agriculture, held at BARC. Dhaka, August, 1991. 24-27.

Biswas, M. A., A.Anwar, R.I. Mondal, M.A. Hossain and R. Uddin. 2009. Integrated Nutrient Management for Sustaining Soil Fertility and Yield of Lentil-MungbeanT.Aman cropping pattern at Jessore Region. Annual Research Report, Pulses Research Centre, BARI, Gagipur, pp 116-119.

Gupta, V.K. and D.S. Mehla. 1993. Depletion of Micronutrients from Soil and Their Uptake in Rice-Wheat Rotation. J. Indian Soc. Soil Sci. 41(4): 704-706.

Harun, R., M.A. Quddus, T. Rahman, H.M. Naser, N.C. Shil and R. Gomes. 2009. Response of chickpea to Zn and B fertilization. Annual Research Report, 2008-09, Soil Science Division, Bangladesh Agricultural Research Institute, Gazipur. pp. 223-229.

Islam, B. 2005. Requirement of boron for Mustard, Wheat and Chickpea based rice cropping patterns. Ph.D. Thesis. Department of Soil Science, Bangladesh Agricultural University, Mymensingh. 124pp.

Islam, M.R., M.R. Karim, T.M. Riasat and M. Jahiruddin. 1996. Growth and yield of BR11 rice under different levels of sulphur, zinc and boron fertility at two locations of Bangladesh. Thai J. Agric. Sci. 29: 37-42. 
Islam, M.S., M.A. Hossain, M.A. Mondol, S. Ahmed, K.U. Ahmad and F. Khatun. 2007. Soil Nutrient Management through Cultivation of Pulses- A system approaches. Bakr M.A., M.A.Afzal and H.U. Ahmed(eds). New Perspectives of Pulses Research In Bangladesh, Proceedings of the national workshop on "Pulses for Nutritional Security and Sustainable Agriculture” held on 24-25 July 2007, BARI, Joydebpur, Gazipur, 235.

Kumar, S. and M. Singh (Eds.). 2009. 25 Years of Pulses Research at IIPR, 1984-2009, Published by: Indian Institute of Pulses Research, Kanpur 208024, India. Pp.68-69.

Noor, S, M.Mahiuddin, N.C. Shil and M.R. Talukder. 2008. Integrated Nutrient Management for Tomato-Okra-Indian Spinach cropping pattern. Annual Research Report, 2007-2008. Shahabuddin khan, Mukhlesr Rahman, S. Noor, M.Hossain and Delowara Khanam (eds.), Division of Soil Science, Bangladesh Agricultural Research Institute, Gazipur. Pp.108-114.

Quddus, M.A., S. Rafiquzzaman, M.R. Rashid, A.T.M. Hossain and A. Hossain. 2008. Comparative economic performance of pulse based alternate cropping patterns at Madaripur District. Int. J. Bio Res. 5(3): 28-31

Rahman, M.T., M.H.R Sheikh and S. Noor. 2009. Integrated Nutrient Management for Sustaining Soil Fertility and Production of Wheat-Mungbean-T.Aman cropping pattern at Isurdi. Annual Research Report, 2008-09. Soil Science Division, Bangladesh Agricultural Research Institute, Gazipur. Pp. 195-198.

Rao, J.V. and R.B.L. Bhardwaj. 1980. Influence of residual fertility on greengram in intensive cropping system. Indian J Agron. 25: 97-101

Sakal, R., R.B. Sinha, and A.P. Singh. 1988. Effect of boron application on blackgram and chickpea production in calcareous soil. Fert. News. 33(2): 27-30.

Sharma, S.K.2005. Techniques and Management of Field Crop Production. Editor P.S. Rathore. Agrobios ( India).

Verma, R.J. and P.H. Mishra. 1999. Effect of doses and methods of boron application on growth and yield of mungbean. Indian J. Pulses Res. 12 (1): 115-118.

Ved Ram, M. Ali, K.U. Mishra and R.M. Upadhyay. 2008. Studies on sulphur, zinc and biofertilizers on yield, yield attributes and nutrient content at different growth stages in mungbean. J. Food Legumes 21(4): 240-242.

Yadav, D.S., K.S. Panwar and V. K. Singh.1997. Management of pulse crops in sequential cropping. Recent Advances in Pulses Research, 1997. A.N. Asthana and Masood Ali Eds., Indian Society of Pulses Research and Development, IIPR, Kanpur, India. pp. 475-487.

Zaman, M.W., S.H. Rahman, B. Moriza and S. Ahmed. 1994. Phosphorus and zinc interaction in rice grain. Prog. Agric. 5(2): 273-278. 